\title{
Definisi paten serta inventor pada produk ASUS
}

\author{
Galih Wicaksono \\ 155100034 \\ Fakultas Komputer, 448757268 \\ galihwicaksono.student@umitra.ac.id
}

\begin{abstract}
ASUS didirikan oleh 4 insyinyur komputer, yaitu Wayne Hseih, Ted Hsu, MT Liao dan TH Tung. Keempatnya memiliki visi dan misi yang sama untuk memajukan industry TI di Taiwan. ASUS sudah memiliki beberapa produk yang mereka buat, diantarnya motherboard, graphic card, nitebook, netbook, produk networking server dan workstation, monitor, produk multimedia, optical storage, peripheral dan aksesoris computer Dan Anti-Dust Cooling. Dengan menggunakan teknologi yang dipatenkan oleh ASUS yaitu Anti-Dust Cooling akan membuat komputer tidak cepat panas walaupun di pakai sampai 48 jam nonstop performa mesin akan tetap lancer walaupun dipakai lama.
\end{abstract}

Kata Kunci : hak paten dan inventor produk asus

\section{A. INTRODUCTION}

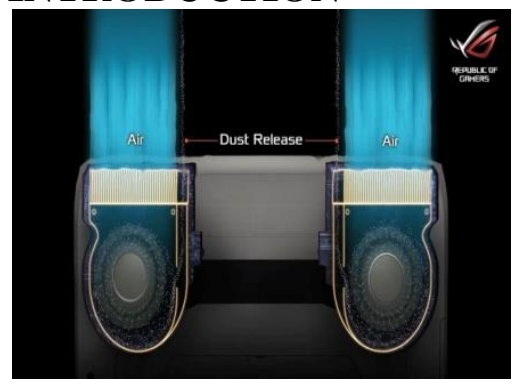

berdirinya ASUS sendiri berdiri pada tahun 1989 yang bermula dari 4 insyinyur komputer, yaitu Wayne Hseih,
Ted Hsu, MT Liao dan TH Tung. Keempatnya memiliki visi dan misi yang sama untuk memajukan industry TI di Taiwan. Awalnya mereka mengambil nama "Pegasus" karena diambil dari mahluk mitologi Yunani. Kemudian seiring perkembangannya, nama tersebut dipersingkat jadi ASUS. ASUS dimulai pada sebuah apartemen kecil di Taipei, Tiwan yang bergerak di 
bidang konsultasi computer

dan belum masuk pada pembuatan hardware. Masuk di dekade 80-an, perusahaan ini mulai menjual konstruksi hardware setelah berhasil membuat dan menjual motherboard untuk prosesor Intel 486.

Dengan semakin berkembangnya perusahaan ini, ASUS sudah memiliki beberapa produk yang mereka buat, diantarnya motherboard, graphic card, nitebook, netbook, produk networking server dan workstation, monitor, produk multimedia, optical storage, peripheral dan aksesoris computer Dan AntiDust Cooling merupakan teknologi yang dipatenkan oleh ASUS, untuk meningkatkan performa pendinginan, dengan teknologi ini ASUS berharap konsumen mendapat kepuasan dari produk-produk ASUS mereka.

\section{B. CONCLUSION}

Dengan menggunakan teknologi yang dipatenkan oleh ASUS yaitu Anti-Dust Cooling akan membuat komputer tidak cepat panas walaupun di pakai sampai 48 jam nonstop performa mesin akan tetap lancer walaupun dipakai lama. Selum anti-drus cooling di patenkan asus sudah mempunya produk mereka sendri yaitu motherboard, graphic card, nitebook, netbook, produk networking server, dan produk mereka laris di pasaran.

\section{ACKNOWLEDGEMENT} University Of Indonesia University Of Mitra Indonesia Telkom University University Of Mellbourne Saitama University 
Conference On Information

Technology And Business (Icitb), 2018, Pp. 181-187.

[2] A. S. Putra, O. M. Febriani, And B. Bachry, "Implementasi Genetic Fuzzy System Untuk Mengidentifikasi Hasil Curian Kendaraan Bermotor Di Polda Lampung," J. Sist. Inf. Dan Manaj. Basis Data, Vol. 1, No. 1, Pp. 21-30, 2018.

[3] O. M. Febriani And A. S. Putra, "Sistem Informasi Monitoring Inventori Barang Pada Balai Riset Standardisasi Industri Bandar Lampung," J. Inform., Vol. 13, No. 1, Pp. 90-98, 2014.

[4] Putra, Arie Setya. "2018 Artikel Struktur Data, Audit Dan Jaringan Komputer." (2018).

[5] Putra, A. S. (2018, July 17). Paperplain Fundamental Create Application With Borland Delphi 7.0 University Of Mitra Indonesia. Retrieved From Osf.Io/Pbrn9.

\section{REFERENCE(Based ISO 690 )}
A. S. Putra And O. M. Febriani, "Knowledge Management Online Application In Pdam Lampung Prosiding

\section{E. REFERENCE $($ (Based APA)}

Putra, A. S., Aryanti, D. R., \& Hartati, I. (2018, November). Metode SAW (Simple Additive Weighting) sebagai Sistem Pendukung Keputusan Guru Berprestasi (Studi Kasus: SMK Global Surya). In Prosiding Seminar Nasional Darmajaya (Vol. 1, No. 1, pp. 85-97). 
Sari, D. P., Febriani, O. M., \& Putra, A. S. (2018, November). Perancangan Sistem Informasi SDM Berprestasi pada SD Global Surya. In Prosiding Seminar Nasional Darmajaya (Vol. 1, No. 1, pp. 289-294).

Putra, A. S. (2018). Paperplain: Execution Fundamental Create Application With Borland Delphi 7.0 University Of Mitra Indonesia.

Putra, A. S., Sukri, H., \& Zuhri, K. Sistem Monitoring Realtime Jaringan Irigasi Desa (JIDES) Dengan Konsep Jaringan Sensor Nirkabel. IJEIS (Indonesian Journal of Electronics and Instrumentation Systems), 8(2), 221232.

Darmawan, A., Yuliawati, D., Marcella, O., \& Firmandala, R. (2016). Sistem Absensi dan Pelaporan Berbasis Fingerprint dan SMS Gateway. EXPLORE, 7(1).

Febriani, O. M., Wahyuni, T., \& Yusuf, S. (2017). DESIGN OF WEBSITE-BASED INFORMATION SYSTEM FOR EDOCUMENT ADMINISTRASI IN THE COMMUNITY SERVICE UNIT (A Case Study at Rajabasa District). INTERNATIONAL JOURNAL OF COMPUTERS \& TECHNOLOGY, 16(7), 7010-7020.

Febriani, O. M., \& Wahyuni, T. (2017, October). PERANCANGAN SISTEM E-DOCUMENT ADMINISTRASI LOGBOOK PENELITIAN PADA UNIT LAYANAN DI BANDAR LAMPUNG. In Prosiding Seminar
Nasional Darmajaya (Vol. 1, No. 1, pp. 187-194).

Febriani, O. M., \& Permadi, A. B. (2017). Implementasi Sistem Aplikasi Data Bimbingan dan Pelanggaran Siswa pada Sekolah Menengah Atas di Lampung Tengah dengan Metode Analisis dan Desain Sistem Terdistribusi (SSAD). EXPERT, 7(1).

Febriani, O. M., \& Ambarwati, L. (2015). PERANCANGAN APLIKASI PENGOLAHAN DATA PENJUALAN UKM KELANTING KHAS TELO DESA SIDOHARJO KECAMATAN JATI AGUNG KABUPATEN LAMPUNG SELATAN. Jurnal Teknologi Informasi dan Bisnis Pengabdian Masyarakat Darmajaya, 1(1), 77-95.

Febriani, O. M. (2015). Rancang Bangun Aplikasi Ecommercemenggunakan Freewebstore pada UKM Kelanting di Desa Sidoharjo Lampung Selatan. Prosiding Sembistek 2014, 1(02), 446-458. 